\title{
Records of Great White Sharks (Carcharodon carcharias) in New Caledonian Waters ${ }^{1}$
}

\author{
Philippe Tirard, ${ }^{2}$ Michael 7. Manning, ${ }^{3,7}$ Isabelle Follit, ${ }^{2,4}$ Clinton Duffy, ${ }^{5}$ and Philippe Borsa $a^{2,6}$
}

\begin{abstract}
The occurrence of great white sharks (Carcharodon carcharias) in New Caledonia is documented from 30 observation events (sightings or captures or forensic examination of wounds) made between 1943 and 2009, involving 34 individual sharks. Nine of the observation events concerned animals caught on lines set for deep-sea fishes, five were encounters with scuba divers or snorkelers, and one was a fatal attack on a surfer; two other observations included great white sharks feeding on whale carcasses; two were from pop-up archival transmitting tag records that monitored individuals tagged in the Chatham Islands, New Zealand; one was a forensic identification from wounds sustained by another large shark; and seven were fortuitous sightings from boats. Nearly all observations were of solitary sharks. Observation events were concentrated in the southern lagoon of New Caledonia or along its barrier reef. They occurred from July to March, with most records in September and November, coinciding with a peak of occurrence of large cetaceans.
\end{abstract}

INFORMATION ABOUT THE distribution, migration, and population structure of one of the largest marine predators, the great white shark, Carcharodon carcharias (L.), is notoriously poor (Pardini et al. 2001, Bonfil et al. 2005), although recent investigations directed at the distribution and migration patterns of this species now make it better known than most other sharks (Boustany et al. 2002, Bonfil et al. 2005, 2010, Bruce et al. 2006, Domeier and Nasby-Lucas 2007, 2008, Weng et al.

\footnotetext{
${ }^{1}$ Manuscript accepted 24 December 2009.

${ }^{2}$ Institut de recherche pour le développement, Nouméa, New Caledonia.

${ }^{3}$ Secretariat of the Pacific Community, Nouméa, New Caledonia.

${ }^{4}$ Université de la Nouvelle-Calédonie, Nouméa, New Caledonia. land.

${ }^{5}$ Department of Conservation, Auckland, New Zea-

${ }^{6}$ Corresponding author. Current address: Institut de recherche pour le développement, Centre de Montpellier, 911 avenue Agropolis, 34032 Montpellier cx, France (e-mail: philippe.borsa@ird.fr).

${ }^{7}$ Deceased 6 September 2009.
}

Pacific Science (2010), vol. 64, no. 4:567-576

doi: $10.2984 / 64.4 .567$

(C) 2010 by University of Hawai'i Press

All rights reserved
2007). The great white shark is globally distributed mainly in temperate waters (Compagno et al. 1997), and investigations on its biology and ecology have traditionally focused on a few temperate or subtropical populations (e.g., Cliff et al. 1996, Strong et al. 1996, Klimley et al. 2001, Hammerschlag et al. 2006, Domeier and Nasby-Lucas 2008). Great white sharks also occur in the tropics (Taylor 1985; FishBase point maps: Froese and Pauly 2007), but the question of whether the records from the tropics reflect permanent distribution or sporadic occurrence has not yet been resolved. Recent tagging experiments using either natural marks or satellitetransmitting archival tags have revealed that great white sharks can make transoceanic migrations and regularly undertake large-scale movements from cool-temperate to tropical waters (Boustany et al. 2002, Bonfil et al. 2005, 2010, Bruce et al. 2006, Weng et al. 2007, Domeier and Nasby-Lucas 2007, 2008). Despite all the tagging data that have been gathered in recent years, further information on behavior and habitat utilization of great white sharks in tropical waters is nevertheless still required. Bonfil et al.'s (2010) data, from pop-up archival tags successfully attached to three great white sharks at the Chatham Islands, suggest that great white 


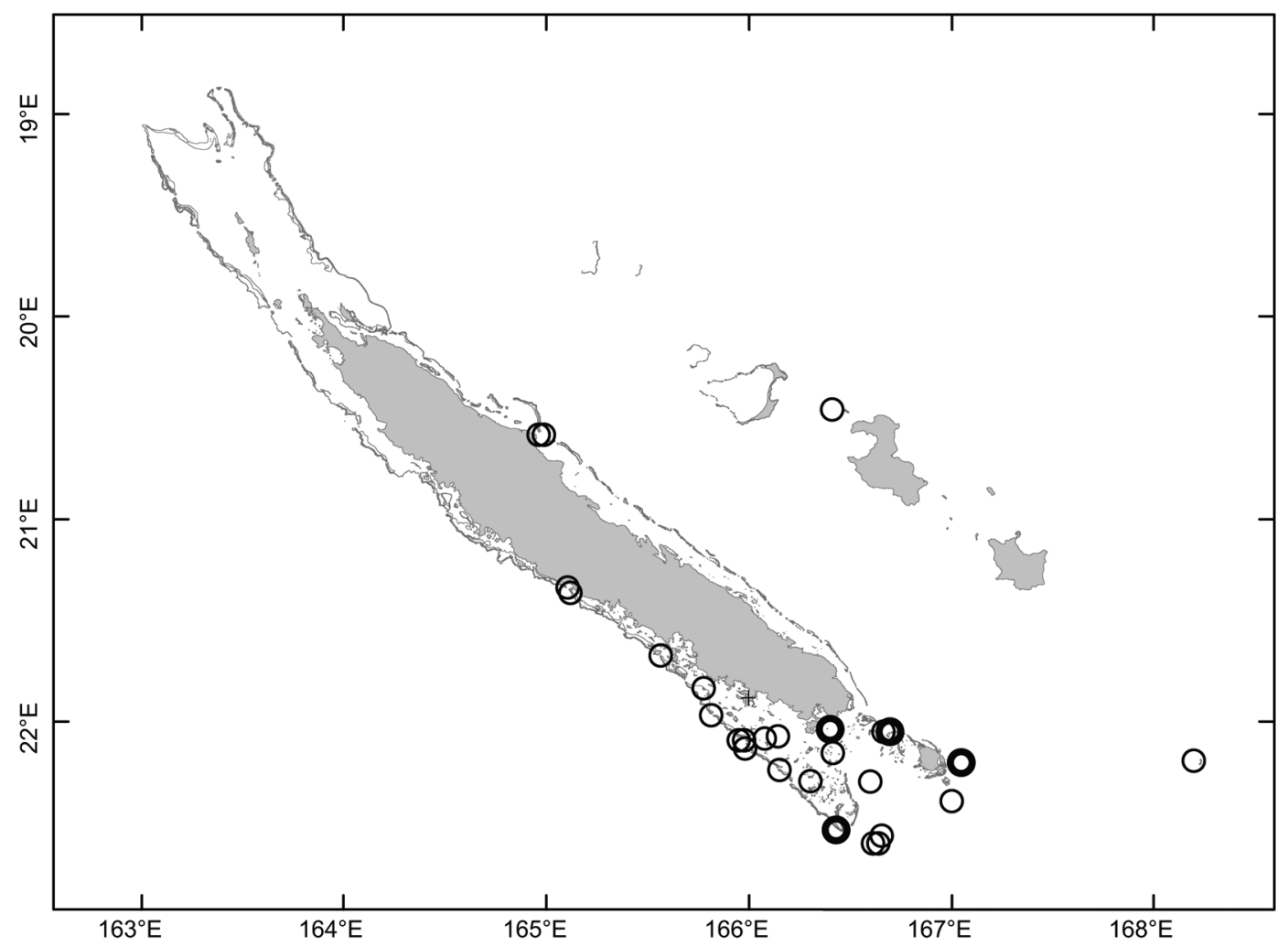

Figure 1. Spatial distribution of great white sharks (Carcharodon carcharias) $(n=31)$ reported from New Caledonian waters over the period 1943-2009. The individual that released its satellite archival tag on 6 October 2005 was localized outside the limits of this map (see Table 1). The precise location of two other individuals was not available (see Table 1). Thin circle, one individual observed; thicker circle, two individuals; cross, Noumea city. Light gray areas represent New Caledonia and surrounding islands; darker gray contours delineate the barrier reef.

sharks may regularly travel from New Zealand to the tropical Southwest Pacific, including New Caledonia and Vanuatu. More data from those tropical islands of the Southwest Pacific are desirable to refine hypotheses on seasonal distributions and migration routes.

Great white sharks have previously been reported from New Caledonia by Fourmanoir and Laboute (1976) and Séret (1994). Here, we review all known records of this species in New Caledonian waters (Figure 1) to document eventual seasonal patterns of occurrence and we relate the latter to the availability of potential prey.

\section{MATERIALS AND METHODS}

New Caledonian waters are defined here as the area adjacent to the island of New Caledonia, eastern Coral Sea (Southwest Pacific) extending seaward from the mean low water mark to the boundary of the Exclusive Economic Zone. In the following, the term "observation event" refers to either capture, or sighting, or other documented occurrence. Observations of great white sharks in New Caledonian waters were compiled from a variety of sources including local newspapers and accounts and photographs from fishermen and divers. 
The Nouméa daily newspaper Nouvelles Calédoniennes reports on events from all across the New Caledonian Archipelago, using a network of local correspondents. The publication of this daily started in 1971. For the period 1971-1997, all the titles of articles published in Nouvelles Calédoniennes have been archived on cardboard files that have been sorted according to one main keyword per article. One of us (P.B.) manually browsed through those archives using the keywords "pêche" (fishing), "plage" (beach), "poissons" (fishes), and "requin" (shark). We consulted either the corresponding original issues of Nouvelles Calédoniennes at Bibliothèque Bernheim, Nouméa, or their copies on microfilm at Service territorial des archives, Nouméa. For the period 1998-2001, we browsed the archives of Nouvelles Calédoniennes then accessible through the Internet (http://archives-lnc.sdv.fr) using the same series of keywords. From January 2002 to March 2009, we checked every issue of this newspaper. Additional observations were obtained from fishermen, scuba divers, snorkelers, and other water users, and five of the observation events reported here were our own.

We also considered the likely spatial and temporal biases in the observation events we reviewed and present them here. We indirectly measured the seasonal distribution of observation effort as follows. One of us (I.J.) undertook aerial surveys of leisure boating and fishing activity in the southern lagoon of New Caledonia from December 2005 to November 2006: during each of 42 aerial surveys evenly distributed over the year, two observers on an airplane noted all boats seen from an altitude of $330 \mathrm{~m}$ along a transect $590 \mathrm{~km}$ long. The null hypothesis of across-season homogeneity of the number of boats at sea was tested by a chi-square test (Sokal and Rohlf 1995).

\section{RESULTS}

\section{Summary of Observations}

Observations of great white sharks in New Caledonian waters are reported in Table 1.
Thirty observation events are documented from 1943 to 2009, involving 34 individual sharks. This constitutes the largest data set on great white shark occurrence in New Caledonian waters collated to date.

The majority $(53 \%)$ of great white shark captures occurred as bycatch on bottom lines set for deep-sea snappers (Etelis spp.) at depths between 150 and $450 \mathrm{~m}$, where sharks were hooked and died entangled in the main line. The remaining captures were made on lines deliberately set for large sharks. Bites on a $3 \mathrm{~m}$ total length (TL) false catshark (Pseudotriakis microdon) caught on a line set at $650 \mathrm{~m}$ depth off Jouan Reef, Loyalty Archipelago, January 2002, consisted of circular series of deep slits 3-6 cm wide, evenly spaced, with 2 to $3 \mathrm{~cm}$ gaps between consecutive slits; the radius of each bite was about $25 \mathrm{~cm}$. These wounds were examined by B. Séret (Institut de recherche pour le développement, Paris), who concluded that they had been inflicted by a great white shark. In one instance, divers photographed two great white sharks from a shark cage off Ugo islet, southern lagoon, using the carcass of a stranded dwarf sperm whale (Kogia sima) as bait (Table 1). Great white sharks scavenging a giant sperm whale (Physeter macrocephalus) carcass had previously been observed in Sarcelle Pass between New Caledonia and Isle of Pines (November 1997 [Table 1]). Two records were from pop-up archival transmitting tag releases in New Caledonian waters (Bonfil et al. 2010) from sharks tagged in the Chatham Islands east of New Zealand's southern island in April 2005. Five reports involved encounters with scuba divers or snorkelers, and one involved a fatal attack on a surfer on the reef off Nessadiou in March 2009 (Table 1). Nearly all observations were of solitary sharks, and the maximum number of sharks seen during the same event was two. All of the events involving two sharks were associated with large windfalls of food: one occurred while beef carcasses were being dumped from a grounded vessel; two were linked to scavenging on whale carcasses; and one was associated with deep-sea fishing.

The smallest individual measured was 2.6 
TABLE 1

Observations of Great White Sharks (Carcharbinus carcharias) in New Caledonian Waters, 1943-2009

\begin{tabular}{|c|c|c|c|c|c|c|c|}
\hline Date & Site & Coordinates & Depth & $n$ & Observation & Voucher & Source $^{a}$ \\
\hline 19 Mar. 1943 & $\begin{array}{l}\text { Nogumatiugi } \\
\text { Reef }\end{array}$ & $\begin{array}{l}22^{\circ} 59^{\prime} \mathrm{S} \\
166^{\circ} 56^{\prime} \mathrm{E}\end{array}$ & Surface & 2 & $\begin{array}{l}\text { Observed from ship Pawnee among many other } \\
\text { sharks attracted by beef carcasses dumped } \\
\text { overboard from grounded vessel Delphinu; } \\
\text { one individual "at least } 15 \text { feet long" captured } \\
\text { using a fishing line }\end{array}$ & - & Mason (1990) \\
\hline 1960 & Touho Pass & $\begin{array}{l}20^{\circ} 47^{\prime} \mathrm{S} \\
165^{\circ} 16^{\prime} \mathrm{E}\end{array}$ & Subsurface & 1 & Captured on fishing line set for sharks & Jaws & $\begin{array}{l}\text { Fourmanoir and Laboute } \\
\quad(1976)\end{array}$ \\
\hline 1971 & Touho Pass & $\begin{array}{l}20^{\circ} 47^{\prime} \mathrm{S} \\
165^{\circ} 16^{\prime} \mathrm{E}\end{array}$ & Subsurface & 1 & (4.2 m), captured on fishing line set for sharks & Jaws & $\begin{array}{l}\text { Fourmanoir and Laboute } \\
\text { (1976) }\end{array}$ \\
\hline 4 Sep. 1979 & $\begin{array}{l}\text { Saint Vincent } \\
\text { Pass }\end{array}$ & $\begin{array}{l}22^{\circ} 01^{\prime} \mathrm{S} \\
165^{\circ} 58^{\prime} \mathrm{E}\end{array}$ & $420 \mathrm{~m}$ & 1 & $\begin{array}{l}\text { (3.8 m), captured by boat Djewe on fishing line } \\
\text { set for deep-sea snapper }\end{array}$ & $\begin{array}{l}\text { Photos; } \\
\text { teeth }\end{array}$ & $\begin{array}{l}\text { Anonymous (1979); P.T., } \\
\text { pers. obs. }\end{array}$ \\
\hline Jan. 1986 & Bourail Pass & $\begin{array}{l}21^{\circ} 39^{\prime} \mathrm{S} \\
165^{\circ} 26^{\prime} \mathrm{E}\end{array}$ & $50-60 \mathrm{~m}$ & 1 & $(\sim 3.0 \mathrm{~m})$, captured on fishing line set for sharks & Photo & $\begin{array}{l}\text { Anonymous (1986); J.-C. } \\
\text { Cazères, pers. comm. }\end{array}$ \\
\hline Nov. 1989 & - & - & - & 1 & $\begin{array}{l}\text { Captured by boat Thalassa on fishing line set for } \\
\text { deep-sea snapper }\end{array}$ & - & Anonymous (1990) \\
\hline $\begin{array}{l}\text { Nov. } 1989- \\
\quad \text { Jan. } 1990\end{array}$ & - & - & - & 1 & $\begin{array}{l}\text { Captured by boat Thalassa on fishing line set for } \\
\text { deep-sea snapper }\end{array}$ & - & Anonymous (1990) \\
\hline 31 Jan. 1990 & Grand Coude & $\begin{array}{l}23^{\circ} 01^{\prime} \mathrm{S} \\
167^{\circ} 10^{\prime} \mathrm{E}\end{array}$ & $450 \mathrm{~m}$ & 1 & $\begin{array}{l}(4.5 \mathrm{~m}) \text {, captured by boat Thalassa on fishing line } \\
\text { set for deep-sea snapper }\end{array}$ & $\begin{array}{l}\text { Photos; } \\
\text { jaws }\end{array}$ & Anonymous (1990) \\
\hline 30 Sep. 1992 & Ua Islet & $\begin{array}{l}22^{\circ} 43^{\prime} \mathrm{S} \\
166^{\circ} 48^{\prime} \mathrm{E}\end{array}$ & $6 \mathrm{~m}$ & 1 & (female, ca. $4 \mathrm{~m}$ ), observed by scuba divers & Photos & $\begin{array}{l}\text { Marmy (1992); Laboute and } \\
\text { Grandperrin (2000) }\end{array}$ \\
\hline 16 Oct. 1994 & Boulari Pass & $\begin{array}{l}22^{\circ} 30^{\prime} \mathrm{S} ; \\
166^{\circ} 27^{\prime} \mathrm{E}\end{array}$ & Surface & 1 & Observed by scuba divers & - & B. Andreani, pers. comm. \\
\hline 4 Jan. 1997 & $\begin{array}{l}\text { Walpole } \\
\text { Island }\end{array}$ & $\begin{aligned} 22^{\circ} 36^{\prime} \mathrm{S} \\
168^{\circ} 56^{\prime} \mathrm{E}\end{aligned}$ & $450 \mathrm{~m}$ & 1 & $\begin{array}{l}\text { (4.5 m), captured on fishing line set for deep-sea } \\
\text { snapper }\end{array}$ & Photo & Martin (1997) \\
\hline Jul. 1997 & $\begin{array}{l}\text { Off Isle of } \\
\text { Pines }\end{array}$ & $\begin{array}{l}22^{\circ} 37^{\prime} \mathrm{S} \\
167^{\circ} 38^{\prime} \mathrm{E}\end{array}$ & Surface & 2 & $\begin{array}{l}\text { Observed from boat Thalassa; one individual ( } 2.6 \\
\text { m), then captured using a fishing line }\end{array}$ & Photo & $\begin{array}{l}\text { Anonymous (1997); J.-P. } \\
\text { Garcia, pers. comm. }\end{array}$ \\
\hline 29 Nov. 1997 & Sarcelle Pass & $\begin{array}{l}22^{\circ} 28^{\prime} \mathrm{S} \\
167^{\circ} 12^{\prime} \mathrm{E}\end{array}$ & Surface & 2 & $\begin{array}{l}\text { (Including } 1 \text { male), observed from boat, feeding } \\
\text { on carcass of a giant sperm whale drifting at } \\
\text { the surface }\end{array}$ & Photos & Bonetti et al. (1998) \\
\hline 15 Nov. 1998 & Grand Coude & $\begin{array}{l}23^{\circ} 04^{\prime} \mathrm{S} \\
167^{\circ} 08^{\prime} \mathrm{E}\end{array}$ & $150-300 \mathrm{~m}$ & 1 & $\begin{array}{l}\text { (4.5 m), captured on fishing line set for deep-sea } \\
\text { snapper }\end{array}$ & Jaws & $\begin{array}{l}\text { Antoine and Le Pêchoux } \\
\text { (1998) }\end{array}$ \\
\hline 16 Nov. 1998 & Grand Coude & $\begin{array}{l}23^{\circ} 04^{\prime} \mathrm{S} ; \\
167^{\circ} 08^{\prime} \mathrm{E}\end{array}$ & $150-300 \mathrm{~m}$ & 1 & $\begin{array}{l}\text { (4.1 m), captured on fishing line set for deep-sea } \\
\text { snapper }\end{array}$ & Jaws & $\begin{array}{l}\text { Antoine and Le Pêchoux } \\
\text { (1998) }\end{array}$ \\
\hline
\end{tabular}




\begin{tabular}{|c|c|c|c|c|c|c|c|}
\hline 27 Jan. 2002 & $\begin{array}{l}\text { Off Jouan } \\
\text { Reef }\end{array}$ & $\begin{array}{l}20^{\circ} 35^{\prime} \mathrm{S} \\
166^{\circ} 58^{\prime} \mathrm{E}\end{array}$ & $650 \mathrm{~m}$ & 1 & $\begin{array}{l}\text { Fresh remains of Pseudotriakis microdon entangled } \\
\text { on fishing line set for alfonsino, from RV Alis }\end{array}$ & Wounds & $\begin{array}{l}\text { Girard (2002); B. Séret, pers. } \\
\text { comm.; P.B., pers. obs. }\end{array}$ \\
\hline Aug. 2002 & Boulari Pass & $\begin{array}{l}22^{\circ} 30^{\prime} \mathrm{S} \\
166^{\circ} 27^{\prime} \mathrm{E}\end{array}$ & $15 \mathrm{~m}$ & 1 & Observed by scuba divers & - & R. Monthouel, pers. comm. \\
\hline 22 Sep. 2002 & $\begin{array}{l}\text { Off Redika } \\
\text { Islet }\end{array}$ & $\begin{array}{l}22^{\circ} 29^{\prime} \mathrm{S} \\
166^{\circ} 30^{\prime} \mathrm{E}\end{array}$ & Surface & 1 & Observed from boat & - & Gavelle (2002) \\
\hline Sep. 2003 & $\begin{array}{l}\text { Off Toombo } \\
\text { Reef }\end{array}$ & $\begin{array}{l}22^{\circ} 33^{\prime} \mathrm{S} ; \\
166^{\circ} 26^{\prime} \mathrm{E}\end{array}$ & Surface & 1 & Observed from boat & - & $\begin{array}{l}\text { F. Larue and P. Larue, pers. } \\
\text { comm. }\end{array}$ \\
\hline Aug. 2005 & Sarcelle Pass & $\begin{array}{l}22^{\circ} 28^{\prime} \mathrm{S} \\
167^{\circ} 12^{\prime} \mathrm{E}\end{array}$ & Surface & 1 & Observed from boat & Photos & Frédière $(2005 a)$ \\
\hline 5 Oct. 2005 & $\begin{array}{l}\text { Off Maré } \\
\text { Island }\end{array}$ & $\begin{array}{l}21^{\circ} 11^{\prime} \mathrm{S} ; \\
169^{\circ} 42^{\prime} \mathrm{E}\end{array}$ & - & 1 & $\begin{array}{l}\text { (Male, } 3.2-3.5 \mathrm{~m} \text { TL) tagged in the Chatham } \\
\text { Islands in April } 2005 \text { by R. Bonfil; last known } \\
\text { position indicated here }\end{array}$ & $\begin{array}{l}\text { Electronic } \\
\text { records }\end{array}$ & $\begin{array}{l}\text { Frédière (2005b); Bonfil et al. } \\
\quad(2010)\end{array}$ \\
\hline 11 Nov. 2005 & Redika Islet & $\begin{array}{l}22^{\circ} 30^{\prime} \mathrm{S} \\
166^{\circ} 38^{\prime} \mathrm{E}\end{array}$ & Surface & 1 & Observed from boats & - & Frédière $(2005 c)$ \\
\hline 14 Dec. 2005 & Tiotibagi Reef & $\begin{array}{l}22^{\circ} 36^{\prime} \mathrm{S} \\
166^{\circ} 56^{\prime} \mathrm{E}\end{array}$ & Surface & 1 & Observed from boat & - & $\begin{array}{l}\text { Ribot (2005); J.-J. Raban, } \\
\text { pers. comm. }\end{array}$ \\
\hline 11 Sep. 2006 & Ugo Islet & $\begin{array}{l}22^{\circ} 27^{\prime} \mathrm{S} \\
166^{\circ} 56^{\prime} \mathrm{E}\end{array}$ & Surface & 2 & $\begin{array}{l}\text { Attracted by carcass of a dwarf sperm whale } \\
\text { used as bait }\end{array}$ & Photos & Frédière (2006) \\
\hline 8 Sep. 2007 & Dumbea Pass & $\begin{array}{l}22^{\circ} 22^{\prime} \mathrm{S} ; \\
166^{\circ} 15^{\prime} \mathrm{E}\end{array}$ & $18 \mathrm{~m}$ & 1 & Male, observed by scuba divers & Photos & Chatel and Bourdil (2007) \\
\hline 7 Nov. 2007 & M'Ba Islet & $\begin{array}{l}22^{\circ} 13^{\prime} \mathrm{S} \\
166^{\circ} 13^{\prime} \mathrm{E}\end{array}$ & Surface & 1 & Observed from boat & Photos & Anonymous (2007) \\
\hline 23 Aug. 2008 & Mato Pass & $\begin{array}{l}22^{\circ} 39^{\prime} \mathrm{S} \\
166^{\circ} 38^{\prime} \mathrm{E}\end{array}$ & Surface & 1 & Female, observed by snorkelers & Photos & Cochin $(2008 b)$ \\
\hline 6 Mar. 2009 & Off Nessadiou & $\begin{array}{l}21^{\circ} 42^{\prime} \mathrm{S} \\
165^{\circ} 28^{\prime} \mathrm{E}\end{array}$ & Surface & 1 & Fatal attack on surfer & Wounds & $\begin{array}{l}\text { Chatel (2009); A. Lafage, pers. } \\
\text { comm.; P.T., pers. obs. }\end{array}$ \\
\hline
\end{tabular}

${ }^{a}$ Includes published material and persons interviewed. 
$\mathrm{m}$ long. There were several sightings of individuals estimated to be $5 \mathrm{~m}$ TL or larger, although the accuracy of these estimates is unknown. Shark sex was seldom recorded, but both males and females were observed (Table 1). Compagno (2001) reported maximum length for great white shark males as between 501 and $517 \mathrm{~cm}$ TL, possibly 550 $\mathrm{cm}$. The observation of an individual larger than that in March 1992 is therefore likely to have been of a female. No neonates or young of the year (i.e., $\leq 165 \mathrm{~cm}$ ) have been recorded from New Caledonian waters. None of the individuals captured was necropsied.

Most observation events were in the southern lagoon of New Caledonia or along its barrier reef (Figure 1). Great white sharks were reported from July to March (Figure 2), with ca. $55 \%$ of the records occurring from September to November.

\section{Seasonal Variation in Observation Effort}

Results of the aerial survey of leisure boating and fishing activity in the southern lagoon are presented in Table 2. Overall, the highest number of boats observed was in summer (January to March) and the lowest in autumn (April to June). The number of boats at sea in

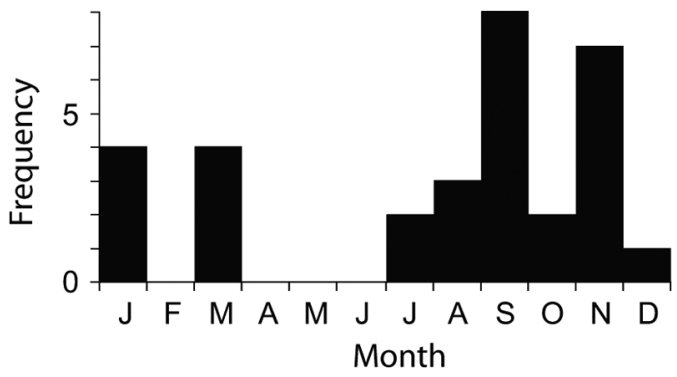

Figure 2. Distribution of observations of great white sharks (Carcharodon carcharias) $(n=31$ individuals) in New Caledonian waters, by month, during the period 1943-2009.

the autumn was about $60 \%$ of that in summer and about $75-80 \%$ of that in winter and spring. We have no reason to suspect that the 2005-2006 year was not representative of general patterns of use of the lagoon. Two great white shark sightings were reported during the survey period, one in September and the other in December.

\section{DISCUSSION}

The failure to collect scientific data from all 13 great white shark specimens captured in

TABLE 2

Evaluation of Temporal Bias in Observation Effort of Great White Sharks (Carcharodon carcharias), Assumed to Be Proportional to Number of Boats at Sea

\begin{tabular}{lllll}
\hline \hline \multirow{2}{*}{$\begin{array}{l}\text { Day of Week } \\
\text { Variable }\end{array}$} & \multicolumn{3}{c}{ Season } \\
\cline { 2 - 5 } & Autumn & Winter & Spring & Summer \\
\hline $\begin{array}{l}\text { Holiday or weekend } \\
\quad \text { Total number of boats }\end{array}$ & 1,437 & 2,103 & & 2,086 \\
$\quad$ Number of aerial surveys) & $(5)$ & $(5)$ & $(5)$ & $(7)$ \\
$\quad$ Average per aerial survey & 287.4 & 420.6 & 241.8 & 298.0 \\
$\begin{array}{l}\text { Working day } \\
\quad \text { Total number of boats }\end{array}$ & 517 & 611 & 1,159 & 1,255 \\
$\quad$ Number of aerial surveys) & $(5)$ & $(5)$ & $(6)$ & $(5)$ \\
$\quad$ Average per aerial survey & 103.4 & 122.2 & 193.2 & 251.0 \\
Any (2 working days for 1 holiday) & 164.7 & 221.7 & 209.4 & 266.7 \\
$\quad$ Average per aerial survey & & & & \\
\hline
\end{tabular}

Note: A total of 42 aerial surveys (each of $3 \mathrm{hr}$, in the morning, $590 \mathrm{~km}$ long, over the southwest lagoon of New Caledonia) was undertaken from December 2005 to November 2006 to count boats. Number of boats is the number spotted by two observers on the airplane along the $590 \mathrm{~km}$ transect; Autumn from 21 March to 21 June; Winter from 21 June to 21 September; Spring from 21 September to 21 December; Summer from 21 December to 21 March. Significant heterogeneity was present in each of the data sets (chi-square test: $P \ll .001)$. 
New Caledonia since 1943 (Table 1) was a lost opportunity. If great white sharks are eventually captured again in New Caledonia, for example as bycatch of the deep-sea snapper fishery, the collection of such data should be given high priority.

Great white sharks in New Caledonian waters were mostly observed as single individuals, as is usual elsewhere in their range except for known hot spots such as False Bay and Seal Island off the southern coast of South Africa, the Farallon Islands in Southern California, and Guadalupe Island off Baja California (Klimley et al. 2001, Hammerschlag et al. 2006, Domeier and NasbyLucas 2008). Most occurrences were in the southern lagoon of New Caledonia or along its barrier reef. However this is also where observer effort was highest: over half of New Caledonia's population is concentrated on the shores of the southern lagoon; in 2005 , about $62 \%$ of the approximately 21,000 boats registered in New Caledonia were based in the Noumea area (communicated by Service de la marine marchande et des pêches maritimes, Nouméa).

Fourmanoir and Laboute (1976) reported that great white sharks seemed to occur in New Caledonian waters only during winter, but Laboute and Grandperrin (2000) suggested that they may be year-round residents offshore. Our data (Figure 2) indicate that great white sharks occur in New Caledonian waters from, at least the beginning of the austral winter to the end of the austral summer, with most records occurring during the spring months (i.e., September to November). We consider that the higher reported occurrence of great white sharks in late winter and spring is unlikely to be an artifact of biased observer effort. Similarly, the low number of sightings over summer and absence of observations in autumn appears to reflect either the absence or substantially lower abundance of great white sharks in or near the New Caledonian lagoon at that time of year.

Great white sharks tagged with satellite tags in temperate Australian and New Zealand waters have been observed to migrate to subtropical and tropical regions of the South- west Pacific during the austral winter (Bruce et al. 2006, Bonfil et al. 2010). It has been proposed that great white sharks leave New Zealand waters to follow the northward migration routes of humpback whales (Megaptera novaeangliae) to their breeding and presumed calving grounds (Bonfil et al. 2010). The sharks tagged in April 2005 and monitored by Bonfil et al. (2010) remained until late June up to September in the vicinity of New Zealand fur seal (Arctocephalus forsteri) rookeries in the Chatham Islands before embarking in oceanic large-scale movements. It is sensible to propose that factors other than whale migration may trigger the departure of great white sharks from New Zealand waters, such as the seaward dispersal of New Zealand fur seals from their rookeries at the end of their breeding period in the austral autumn. Fur seals have been recorded from New Caledonian waters from July to September (Bonetti 1997, Borsa 2006, Cochin 2008a, Pion 2009), and of the seven fur seals recorded in New Caledonia, all three that were identified to species were New Zealand fur seals. Thus, great white sharks from New Zealand may not only follow the migration routes of humpback whales but also the movements of New Zealand fur seals and perhaps those of other potential prey.

Great white sharks prey upon a wide variety of marine animals (Long 1991, Stewardson 1999, Fergusson et al. 2000, Klimley et al. 2001, Estes et al. 2003, Curtis et al. 2006, Fitzpatrick et al. 2006, Hammerschlag et al. 2006, Dicken 2008) and probably feed opportunistically on any large marine vertebrate. It is reasonable to assume that the concentration of breeding humpback whales in New Caledonian waters in the austral winter, from June to October (Garrigue and Gill 1994, Garrigue et al. 2002; P.B., unpubl. data), may explain, in part, the apparently higher abundance of great white sharks in those areas at the same time period. Humpback whale placentas, stillborn calves, cows undergoing problematic parturition, or bulls injured in fights with congeners are all likely to be attractive prey items to great white sharks. Sperm whale abundance in New Caledonian waters is also highest from August to 
December, with a marked peak in September, as is that of the pygmy sperm whale (Borsa 2006) and that of fur seals (as mentioned in the preceding paragraph). Although the occurrence of great white sharks in the winter and spring may be related to that of those highly energetic food sources, other explanations have to be sought for the extension of great white shark occurrence in New Caledonian waters up to the end of summer. Other potential prey of great white sharks in New Caledonia are dugong (Dugong dugon) and other marine mammals, sea turtles, and deep-sea snappers, tunas, and other large fishes, all of which occur year-round in New Caledonian waters. It is also possible that a proportion of the great white sharks observed in New Caledonian waters are resident yearround or most of the year, with transient sharks from around New Zealand or possibly elsewhere also occurring in the austral winter and spring.

Our records of great white sharks from New Caledonia, together with the pop-up archival tag data of Bonfil et al. (2010), should be compared with the data recently gathered on groups of sharks studied off central California and around Guadalupe Island, Mexico (Domeier and Nasby-Lucas 2007, 2008, Weng et al. 2007). Sharks from the North-East Pacific move from their temperate California and Guadalupe Island concentration areas to tropical waters on a seasonally predictable pattern, and individual sharks show extreme philopatry for the temperate portion of their geographic range, but the extent of the fidelity to their tropical destinations is still unknown (Domeier and Nasby-Lucas 2008). Bonfil et al.'s (2010) and our data suggest that the large-scale movement routes and timing in the Southwest $\mathrm{Pa}$ cific may be symmetrical to those discovered in the Northeast Pacific. Future research programs should consider tagging individuals in New Caledonia to determine whether great white sharks make return migrations to temperate waters and, if so, at which time of the year. Whether the large-scale movements from temperate to tropical waters in the Southwest Pacific are related to offshore par- turition and mating, and not only foraging as assumed so far (Bonfil et al. 2010), also remains to be investigated.

\section{ACKNOWLEDGMENTS}

We are grateful to P. Larue for sharing his archives with us. We thank B. Andreani, J.-C. Cazères, J.-P. Garcia, A. Lafage, R. Monthouel, and J.-J. Raban for excellent information; and B. Séret (IRD, Paris) for identifying both the false catshark and the wounds on it. Thanks extended to V. Allain (Secretariat of the Pacific Community) for facilitating the first meeting between M.J.M., P.B., and P.T. Helpful advice was offered by A. Boustany, M. Domeier, and an anonymous reviewer. Funds for aerial surveys were from ZoNéCo.

\section{Literature Cited}

Anonymous. 1979. Par 420 mètres de fond, un requin blanc a été pris samedi près de Saint-Vincent. Nouvelles Calédoniennes 2477:26.

. 1986. Les requins de Bourail. Nouvelles Calédoniennes 4398:20.

- 1990. Un requin blanc au Grand Coude. Nouvelles Calédoniennes 5623:2.

- 1997. « Thalassa » a ramené un requin blanc. Nouvelles Calédoniennes 7852:8.

2007. Un grand blanc à M'Ba. Nouvelles Calédoniennes 10996:3.

Antoine, C., and M. Le Pêchoux. 1998. Prises exceptionnelles dans les eaux du Territoire: Deux requins blancs se mêlent à la pêche du Thalassa. Nouvelles Calédoniennes 8262:16.

Bonetti, O. 1997. Une otarie aperçue au phare Amédée. Nouvelles Calédoniennes 7874:6.

Bonetti, O., B. Civet, and S. Bourreau. 1998. Le festin des requins. Nouvelles Calédoniennes 8004:4-5.

Bonfil, R., M. P. Francis, C. Duffy, M. J. Manning, and S. M. O'Brien. 2010. Large-scale tropical movements and diving 
behavior of white sharks (Carcharodon carcharias) tagged off New Zealand. Aquat. Biol. 8:115-123.

Bonfil, R., M. Meer, M. C. Scholl, R. Johnson, S. O'Brien, H. Oosthuizen, S. Swanson, D. Kotze, and M. Paterson. 2005. Transoceanic migration, spatial dynamics, and population linkages of white sharks. Science (Washington, D.C.) 70:100-103.

Borsa, P. 2006. Marine mammal strandings in the New Caledonia region, Southwest Pacific. C. R. Biol. 329:277-288.

Boustany, A. M., S. F. Davis, P. Pyle, S. D. Anderson, B. J. Le Boeuf, and B. A. Block. 2002. Expanded niche for white sharks. Nature (Lond.) 415:35-36.

Bruce, B. D., J. D. Stevens, and H. Malcolm. 2006. Movements and swimming behaviour of white sharks (Carcharodon carcharias) in Australian waters. Mar. Biol. (Berl.) 150:161-172.

Chatel, P. 2009. Drame de Bourail: c'était un requin blanc. Nouvelles Calédoniennes 11404:4.

Chatel, P., and L. Bourdil. 2007. Nez à nez avec un grand blanc. Nouvelles Calédoniennes 10942:1-2.

Cliff, G., R. P. Van der Elst, A. Govender, T. K. Witthuhn, and E. M. Bullen. 1996. First estimates of mortality and population size of white sharks on the South African coast. Pages 393-400 in A. P. Klimley, and D. G. Ainley, eds. Great white sharks: The biology of Carcharodon carcharias. Academic Press, San Diego.

Cochin, C. 2008a. Une otarie fait escale en face de Poum. Nouvelles Calédoniennes 11206:4.

- 2008b. Des chasseurs sous-marins nagent aux côtés d'un grand blanc. Nouvelles Calédoniennes 11239:3.

Compagno, L. J. V. 2001. Sharks of the world. An illustrated and annotated catalogue of shark species known to date. Vol. 2. Bullhead, mackerel and carpet sharks (Heterodontiformes, Lamniformes and Orectolobiformes). FAO Species Catalogue for Fishery Purposes 1. FAO, Rome.

Compagno, L. J. V., M. A. Marks, and I. K. Fergusson. 1997. Threatened fishes of the world: Carcharodon carcharias (Linnaeus, 1758) (Lamnidae). Environ. Biol. Fishes 50:61-62.

Curtis, T. H., J. T. Kelly, K. L. Menard, R. K. Laroche, R. E. Jones, and A. P. Klimley. 2006. Observations on the behavior of white sharks scavenging from a whale carcass at Point Reyes, California. Calif. Fish Game 92:113-124.

Dicken, M. L. 2008. First observations of young of the year and juvenile great white sharks (Carcharodon carcharias) scavenging from a whale carcass. Mar. Freshwater Res. 59:596-602.

Domeier, M. L., and N. Nasby-Lucas. 2007. Annual re-sightings of photographically identified white sharks (Carcharodon carcharias) at an eastern Pacific aggregation site (Guadalupe Island, Mexico). Mar. Biol. (Berl.) 150:977-984.

- 2008. Migration patterns of white sharks Carcharodon carcharias tagged at Guadalupe Island, Mexico, and identification of an eastern Pacific shared offshore foraging area. Mar. Ecol. Prog. Ser. 370:221-237.

Estes, J. A., B. B. Hatfield, K. Ralls, and J. Ames. 2003. Causes of mortality in California sea otters during periods of population growth and decline. Mar. Mamm. Sci. 19:198-216.

Fergusson, I. K., L. J. V. Compagno, and M. A. Marks. 2000. Predation by white sharks Carcharodon carcharias (Chondrichthyes: Lamnidae) upon chelonians, with new records from the Mediterranean Sea and a first record of the ocean sunfish Mola mola (Osteichthyes: Molidae) as stomach contents. Environ. Biol. Fishes 58:447-453.

Fitzpatrick, B., M. Meekan, and A. Richards. 2006. Shark attacks on a whale shark (Rbincodon typus) at Ningaloo Reef, western Australia. Bull. Mar. Sci. 78:397402.

Fourmanoir, P., and P. Laboute. 1976. Poissons de Nouvelle-Calédonie et des Nouvelles-Hébrides. Editions du Pacifique, Papeete.

Frédière, P. 2005a. Deux requins blancs re- 
pérés dans le sud calédonien. Nouvelles Calédoniennes 10348:6.

. 2005b. Un troisième requin blanc au large de Maré. Nouvelles Calédoniennes 10349:4.

2005c. Un grand blanc bouscule une plate à l'îlot Redika. Nouvelles Calédoniennes 10381:5.

2006. Deux requins blancs observés au large de Prony. Nouvelles Calédoniennes 10635:3.

Froese, R., and D. Pauly. 2007. FishBase. World Wide Web electronic publication. www.fishbase.org, version. Accessed July 2007.

Garrigue, C., A. Aguayo, V. L. U. AmanteHelweg, C. S. Baker, S. Caballero, P. Clapham, R. Constantine, J. Denkinger, M. Donoghue, L. Flórez-González, J. Greaves, N. Hauser, C. Olavarría, C. Pairoa, H. Peckham, and M. Poole. 2002. Movements of humpback whales in Oceania, South Pacific. J. Cetacean Res. Manage. 4:255-260.

Garrigue, C., and P. C. Gill. 1994. Observations of humpback whales Megaptera novaeangliae in New Caledonian waters during 1991-1993. Biol. Conserv. $70: 211-218$.

Gavelle, J. 2002. Les « dents de la mer » dans le lagon. Nouv. Calédoniennes 9429:5.

Girard, H. 2002. Deux nouvelles espèces de requin découvertes par l'IRD. Nouvelles Calédoniennes 9276:10.

Hammerschlag, N., R. A. Martin, and C. Fallows. 2006. Effects of environmental conditions on predator-prey interactions between white sharks (Carcharodon carcharias) and Cape fur seals (Arctocephalus pusillus pusillus) at Seal Island, South Africa. Environ. Biol. Fishes 76:341-350.

Klimley, A. P., B. J. Le Boeuf, K. M. Cantara, J. E. Richert, S. F. Davis, S. Van Sommeran, and J. T. Kelly. 2001. The hunting strategy of white sharks (Carcharodon carcharias) near a seal colony. Mar. Biol. (Berl.) 138:617-636.

Laboute, P., and R. Grandperrin. 2000. Poissons de Nouvelle-Calédonie. Editions Catherine Ledru, Nouméa.

Le Pêchoux, M. 1992. Un requin blanc de 7 mètres. Nouvelles Calédoniennes 6268:1, 5.

Long, D. J. 1991. Apparent predation by a white shark Carcharodon carcharias on a pygmy sperm whale Kogia breviceps. Fish. Bull. (U.S.) 89:538-540.

Marmy, J. 1992. Un requin blanc dans le lagon. Nouvelles Calédoniennes 6414:1, 24.

Martin, M. 1997. Un requin blanc pris à la palangre. Nouvelles Calédoniennes 7704:8.

Mason, T. C. 1990. We will stand by you: Serving in the Pawnee, 1942-1945. University of South Carolina Press, Columbia.

Pardini, A. T., C. S. Jones, L. R. Noble, B. Kreiser, H. Malcolm, B. D. Bruce, J. D. Stevens, G. Cliff, M. C. Scholl, M. Francis, C. A. J. Duffy, and A. P. Martin. 2001. Sex-biased dispersal of great white sharks. Nature (Lond.) 412:139-140.

Pion, G. 2009. Une otarie dans le lagon d'Ouvéa. Nouv. Calédoniennes 11547:3.

Ribot, S. 2005. Rencontre avec le grand blanc: Les pêcheurs racontent. Nouvelles Calédoniennes 10408:4.

Séret, B. 1994. Chondrichthyan fishes of New Caledonia. Chondros 5:6-9.

Sokal, R. R., and F. J. Rohlf. 1995. Biometry, 3rd ed. Freeman and Co., New York.

Stewardson, C. L. 1999. Preliminary investigations of shark predation on Cape fur seals Arctocephalus pusillus pusillus from the Eastern Cape coast of South Africa. Trans. R. Soc. S. Afr. 54:191-203.

Strong, W. R., Jr, B. D. Bruce, D. R. Nelson, and R. D. Murphy. 1996. Population dynamics of white sharks in Spencer Gulf, South Australia. Pages 401-414 in A. P. Klimley, and D. G. Ainley, eds. Great white sharks: The biology of Carcharodon carcharias. Academic Press, San Diego.

Taylor, L. 1985. White sharks in Hawaii: Historical and contemporary records. Mem. South Calif. Acad. Sci. 9:41-48.

Weng, K. C., A. M. Boustany, P. Pyle, S. D. Anderson, A. Brown, and B. A. Block. 2007. Migration and habitat of white sharks (Carcharodon carcharias) in the eastern Pacific Ocean. Mar. Biol. (Berl.) 152:877-894. 